\title{
THE DETERMINATION OF MAJOR AND SOME MINOR CONSTITUENTS IN LEAD ZIRCONATE-TITANATE COMPOSITIONS BY X-RAY FLUORESCENCE AND ATOMIC ABSORPTION SPECTROMETRY
}

\author{
J. H. H. G. VAN WILLIGEN. H. KRUIDHOF and E. A. M. F. DAHMEN
}

Twente University of Techmology, P.O. Box 217. Enschede (The Netherlands)

(Received 15th June 1972)

Compositions of lead zirconate-titanate (PZT) are of great interest for manufacturing piezo-electric ceramics. During manufacture selective volatilization of elements can occur in high-temperature treatments. Therefore, the chemical composition of these materials should be determined after these treatments. Further, the a mounts of unreacted oxides must be known for production control. Analytical procedures for this purpose have been described by Goode et $a l .{ }^{1}$ and by Robinson and Joyce ${ }^{2}$.

However, relatively accurate determinations of minor additions of elements ("dopes") are also required. Here, emission spectroscopy, as described by Mirti and Shivak ${ }^{3}$, lacks the accuracy desired and few other analytical methods have been proposed in the literature to solve this problem.

Moreover, these analytical procedures may run into difficulties, if certain minor constituents are present, and the sophisticated instruments described may not be ceasily avaijabie. X-Ray juorescence speciromenry carrieo oul wirn suirabie standards and homogeneous samples is very precise, accurate and highly selective. In addition, the application of a borax fusion technique for sample preparation ${ }^{4}$ enables sufficient exclusion of matrix effects on determinations of elements. Along these lines, together with analysis by means of atomic absorption, it was possible to achieve satisfactory analysis of PZT composition. This paper describes the development of the X-ray fluorescence spectrometric methods for the determination of lead, zirconium and titanium as major constituents, the determination of minor constituents (K, La, Sm, Yb) and the determination of some of the unreacted oxides $\left(\mathrm{Zr}\left(\mathrm{D}_{2}\right.\right.$ and $\left.\mathrm{T}_{1} \mathrm{O}_{2}\right)$. Alomic absorplion spectrometric methods bave a)so been deve)oped for cases ( $\mathrm{PbO}, \mathrm{Mg}$ ) where X-ray fluorescence seemed less appropriate. The methods described are applicable, with obvious modifications, to many types of materials.

Total lead, zirconium and titanium

The above major constituents were determined by X-ray fluorescence spectrometry, consideration being given to the following points ${ }^{\star}$.

For precise results, standards and samples should be matched closely. Where

$\star$ In this section "intensity" means the number of counts per fixed time measured with the X-ray fluorescence spectrometer on the line of the element.

Anal. Chim. Acia. 62 (1972) 
a large variation in sample composition is expected, this is most easily done by a sample pretreatment, e.g. dilution in molten borax and addition of a heavy absorber. Here the general method previously described ${ }^{4}$ was used; standards are easily prepared from assayed compounds of the elements of interest.

Although a high dilution combined with a large amount of heavy absorber is applied, changes in concentration of a major element (e.g. lead) can still influence to some extent the intensity of any other element (e.g. zirconium), even when the latter does not change in concentration. The occurrence and degree of mutual influence was tested as follows: standards were prepared containing zirconium and titanium and varying amounts of lead by mixing the appropriate amounts of oxides; next these were analysed as described under the heading procedures.

From the intensities measured it appeared that: (a) the calibration line of zirconium is linear: (b) the variation in lead content has an influence, although small, on the zirconium intensity; and (c) this influence is proportional to the lead content (Fig. 1).

For titanium a similar, but smaller, effect from the lead content was measured. However, there was no perceptible influence from zirconium on titanium or vice versa. nor had zirconium or titanium any perceptible influence on the lead intensity.

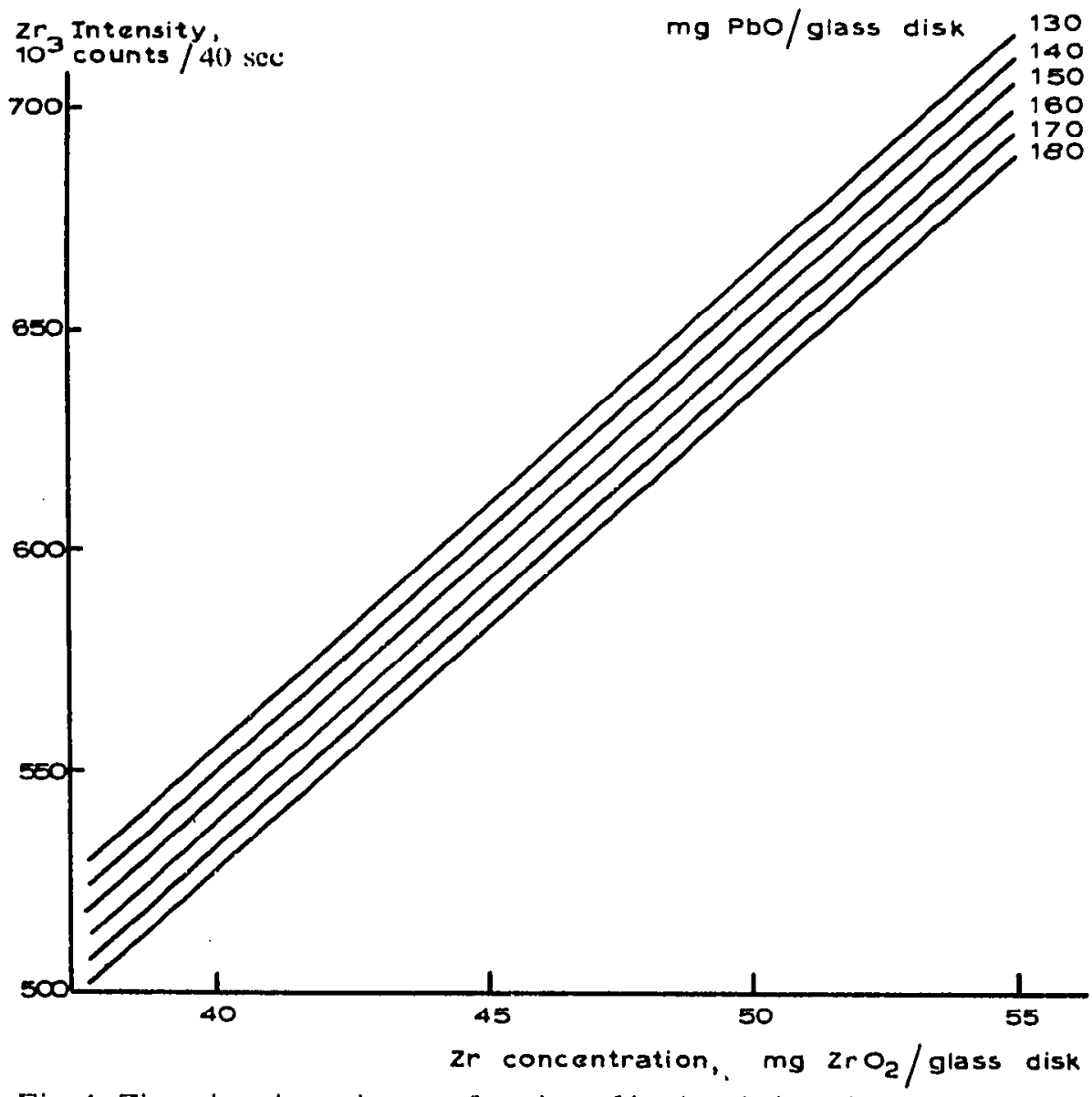

Fig. 1. Zirconium intensity as a function of lead and zirconium concentration.

Anal. Chim. Acta, 62 (1972) 
In the present procedure, the following formulae were applied to calculate the lead, zirconium and titanium concentrations $c$ (element) from the intensities $I$ (element) measured:

$$
\begin{aligned}
& c(\mathrm{~Pb})=k 1 \cdot I(\mathrm{~Pb})+k 2 \\
& c(\mathrm{Zr})=k 3 \cdot I(\mathrm{Zr})+k 4 \cdot I(\mathrm{~Pb})+k 5 \\
& c(\mathrm{Ti})=k 6 \cdot I(\mathrm{Ti})+k 7 \cdot l(\mathrm{~Pb})+k 8
\end{aligned}
$$

where $k 1, k 2, \ldots, k 8$ are constants determined from the standards used to obtain Fig. 1 and similar experiments concerning the mutual influence of other pairs of elements. Once the above linear relationships have been established, only three well chosen standards are needed to calculate the constants $k 1, k 2, \ldots, k 8$.

The X-ray fluorescence spectrometer used had a sample changer with 4 positions. To obtain high accuracy it was necessary to consider possible differences between these 4 positions. In the instrument available, adjustment to a difference between positions smaller than $0.1 \%$ proved impossible; for most work this is quite acceptable. Measurement in the same position of the sample changer was advisable for the highest accuracy; at the same time sample holders were selected to be as equal as possible.

Occasionally a "burst". probably caused by external electronical interference, gave rise to a high number of counts. In order to detect such interferences, samples and standards were always counted at least twice.

For routine use it was not necessary to establish a calibration line every day. Once a calibration line had been obtained, only one of the standards was measured for each series of samples, in order to correct the sample intensity for daily variations of the spectrometer.

\section{Dope elements}

The X-ray fluorescence spectrometer available was unable to determine magnesium: therefore an atomic-absorption spectrophotometric method was developed. Because of the large influence of the major elements on the magnesium absorption. a standard addition method was applied to account for large variations in sample composition.

The other elements were determined by X-ray fluorescence spectrometry, with an internal standard to compensate for the effect of matrix (i.e. sample composition) variations. The internal standard element was chosen so that the mass-absorption coefficients of the sample for the wavelength of the element to be determined and for the wavelength of the internal standard were as equal as possible. These wavelengths should not differ much. The amount of the internal standard element was selected so that the count rates of internal standard and dope elements in the concentration region of interest were approximately equal. The choice of the internal standard may be limited for practical reasons, e.g. when barium was used as internal standard for lanthanum, it appeared impossible to keep the glass discs intact, whereas cerium proved satisfactory.

\section{Unreacted oxides}

The methods described by Robinson and $\mathrm{J}_{0 y c e}{ }^{2}$ were used to separate the unreacted oxides from the reaction product PZT. The lead oxide was dissolved in 
TABLE I

INSTRUMENTAL CONDITIONS FOR THE DETERMINATION OF ELEMENTS BY X-RAY FLUORESCENCE SPECTROMETRY

\begin{tabular}{|c|c|c|c|c|c|}
\hline Element & $\begin{array}{l}P b \\
\text { (total) }\end{array}$ & $\begin{array}{l}Z r \\
\text { (tolal) }\end{array}$ & $\begin{array}{c}\not z r \\
\text { (unreacled) }\end{array}$ & $\begin{array}{l}\text { ri } \\
\text { (toral) }\end{array}$ & $\begin{array}{l}T i \\
\text { (unreacted) }\end{array}$ \\
\hline X-ray tube & $\mathbf{w}$ & $\mathbf{w}$ & $\mathbf{w}$ & $\mathrm{Cr}$ & $\mathrm{Cr}$ \\
\hline High tension, kV & 50 & 50 & 50 & 40 & 50 \\
\hline Current, mA & 20 & 20 & 20 & 24 & 20 \\
\hline Radiation path & air & air & air & vacuum & vacuum \\
\hline Collimator & fine & fine & Finc & coarse & coarse \\
\hline Analyzing crystal & $\operatorname{LiF}(200)$ & $\operatorname{LiF}(200)$ & $\operatorname{LiF}(200)$ & $\operatorname{LiF}(200)$ & $\operatorname{LiF}(200)$ \\
\hline Line & $\mathbf{L} \alpha_{1.2}$ & $\mathrm{~K} \alpha_{1.2}$ & $\mathrm{~K} \alpha_{1,2}$ & $K \alpha_{1,2}$ & $K \alpha_{1,2}$ \\
\hline Detector & scint.c & scint.c & scint.c & How c & hlow c \\
\hline Vollage (V) & 850 & 825 & 825 & 1650 & 1650 \\
\hline Attenuator position & 2 & 2 & 2 & 4 & 4 \\
\hline Pulse height discrimination & no & no & no & no & no \\
\hline Lower level scale & 150 & 150 & 150 & 150 & 150 \\
\hline Window scale & - & - & -- & -.. & $\cdots$ \\
\hline Counting time, s. & 40 & 40 & 100 & 40 & 100 \\
\hline Approx. net no. of counts & 770,000 & 650,000 & 150,000 & 760,000 & 70,000 \\
\hline For a conc in the orig. sample, $\%$ & 63 & 15 & 0.6 & 7.2 & 0.1 \\
\hline Internal standard used & $\ldots$ & $\ldots$ & $\ldots$ & $\cdots \cdots$ & $\cdots$ \\
\hline $\begin{array}{l}\text { Amount (mg) and compound used, } \\
\text { respectively }\end{array}$ & $\ldots$ & $\cdots$. & $\cdots$ & $\cdots$ & $\cdots$ \\
\hline Diam. of sumple holder bottom hole, $\mathrm{mr}$ & n 28 & 28 & 23 & 28 & 23 \\
\hline
\end{tabular}

\begin{tabular}{|c|c|c|c|c|c|c|c|}
\hline $\begin{array}{l}K \\
\text { (dope) })\end{array}$ & $\begin{array}{l}C a \\
\text { (int.st.) }\end{array}$ & $\begin{array}{l}\text { La } \\
\text { (dope) }\end{array}$ & $\begin{array}{l}\text { Cet } \\
\text { (int.st.) }\end{array}$ & $\begin{array}{l}\text { Sim } \\
\text { (dope) }\end{array}$ & $\begin{array}{l}C r \\
(\text { int.st. })\end{array}$ & $\begin{array}{l}Y b \\
\text { (clope) }\end{array}$ & $\begin{array}{l}N i \\
\text { (int.st.) }\end{array}$ \\
\hline $\mathrm{Cr}$ & $\mathrm{Cr}$ & w & w & W & W & w & $\mathbf{w}$ \\
\hline 50) & 50 & 50 & 50 & 50 & 50 & 50 & 50 \\
\hline 20 & 20 & 20 & 20 & 20 & 20 & 20 & 20 \\
\hline vacuum & vacuum & vacuum & vacuum & vacuum & vacuum & vacuum & vacuum \\
\hline coarse & coarse & coarse & coarse & fine & fine & fine & fine \\
\hline PE & PE & $\operatorname{LiF}(200)$ & $\operatorname{LiF}(200)$ & $\operatorname{LiF}(200)$ & $\operatorname{LiF}(200)$ & $\operatorname{LiF}(220)$ & $\operatorname{LiF}(220)$ \\
\hline $\mathrm{K} \alpha_{1,2}$ & $K \alpha_{1.2}$ & $L \alpha_{1,2}$ & $L \beta_{1}$ & $\mathrm{~L} \alpha_{1,2}$ & $\mathrm{~K} \alpha_{1,2}$ & $L \alpha_{1,2}$ & $\mathrm{~K} \alpha_{1,2}$ \\
\hline Hlow c & hlow c & How c & hlow c & flow c & $\begin{array}{l}\text { flow c } \\
1650\end{array}$ & $\begin{array}{l}\text { scint.c } \\
900\end{array}$ & $\begin{array}{l}\text { scint.c } \\
900\end{array}$ \\
\hline $\begin{array}{l}1600 \\
3\end{array}$ & $\begin{array}{l}1600 \\
3\end{array}$ & $\begin{array}{l}1650 \\
4\end{array}$ & 1650 & $\begin{array}{l}1650 \\
4\end{array}$ & $\begin{array}{l}1650 \\
4\end{array}$ & 2 & $\begin{array}{l}900 \\
2\end{array}$ \\
\hline $\begin{array}{l}3 \\
\text { no }\end{array}$ & $\begin{array}{l}3 \\
\text { no }\end{array}$ & $\begin{array}{l}4 \\
\text { yes }\end{array}$ & 4 & $\begin{array}{l}4 \\
\text { no }\end{array}$ & $\begin{array}{l}4 \\
\text { no }\end{array}$ & no & no \\
\hline $\begin{array}{l}\text { no } \\
150\end{array}$ & $\begin{array}{l}\text { no } \\
150\end{array}$ & $\begin{array}{l}\text { yes } \\
350\end{array}$ & $\begin{array}{l}\text { yes } \\
350\end{array}$ & $\begin{array}{l}\text { no } \\
150\end{array}$ & $\begin{array}{l}\text { no } \\
150\end{array}$ & 150 & 150 \\
\hline$\ldots$ & - & 200 & $\begin{array}{l}500 \\
200\end{array}$ & - & $\ldots$ & - & - \\
\hline 40 & 40 & 40 & 40 & 40 & 40 & 40 & 40 \\
\hline 100,000 & 300,000 & 80,000 & 100,000 & 75,000 & 150,000 & 80,000 & 330,000 \\
\hline 0.3 & $\ldots$ & 1.5 & -- & 1.5 & $\ldots$ & 1.5 & - \\
\hline $\mathrm{Ca}$ & - & $\mathrm{Cc}$ & - & $\mathrm{Cr}$ & - & $\mathrm{Ni}$ & - \\
\hline 30 & $\mathrm{CaCO}_{3}$ & 50 & $\mathrm{CeO}_{2}$ & 80 & $\mathrm{~K}_{2} \mathrm{Cr}_{2} \mathrm{O}_{7}$ & 40 & $\mathrm{NiO}$ \\
\hline 28 & 28 & 20 & 20 & 20 & 20 & 28 & 28 \\
\hline
\end{tabular}


EDTA $(0.02 M)$, but a back-titration of the excess of EDTA ${ }^{2}$ appeared unattractive. A direct method of determination was applied. Here, $X$-ray fluorescence spectrometry might have been used. but atomic-absorption spectrometry is much quicker. The $283.3 \mathrm{~nm}$ line of lead was chosen, because this line is less prone to interferences and is sufficiently sensitive, that no dilution or concentration of the extracted lead solution was necessary.

The acid-insoluble residue (zirconium oxide and titanium oxide) was taken into a borax melt and determined by $\mathrm{X}$-ray fluorescence spectrometry; sodium chloride was added to prevent cracking of the glass disc.

\section{EXPERIMENTAL.}

\section{Apparatus}

Some of the instrumental conditions applied for the determination of the elements with a Philips PW 1540 XRF spectrometer are shown in Table I; further, use was always made of the sample spinner.

The instrumental conditions applied for the determination of the elements by means of a Jarrell-Ash 82-547 atomic-absorption spectrophotonieter are shown in Table 11. The instrument was provided with a premix Techtron A B51 laminar burner, and a total consumption Hetco turbulent burner. Westinghouse hollow-cathode lamps were used. A Hamamatsu R213 photomultiplier and a grating blazed for 300 $\mathrm{nm}$ were used. Entrance and exit slits of the monochromator were 100 and $150 \mu \mathrm{m}$ respectively. For the Hetco burner the light was passed 5 times through the flame. For both lead and magnesium determinations, hydrogen and air were the fuel and oxidant gases, respectively.

TABLE H

INSTRUMENTAL CONDITIONS FOR THE DETERMINATION OF THE ELEMENTS BY ATOMIC ABSORPTION SPECTROMETRY

\begin{tabular}{|c|c|c|}
\hline Element & $\mathrm{Pb}$ & Mg \\
\hline Wavelength, am & 283.3 & 285.2 \\
\hline Burner & Techtron & Helco \\
\hline $\begin{array}{l}\text { Hollow cathode lamp. } \\
\text { current, } \mathrm{mA}\end{array}$ & 6 & 8 \\
\hline Photomultiplier voltage, $V$ & 380 & 380 \\
\hline Gas pressure. $k \mathrm{~g} \mathrm{~cm}^{-2}$ & 4 & 4 \\
\hline Gas flow. $1 \mathbf{h}^{-1}$ & 10 & 13 \\
\hline Oxidant pressure, $\mathrm{kg} \mathrm{\textrm {cm } ^ { - 2 }}$ & 4 & 4 \\
\hline Oxidant fow $1 \mathrm{~h}-1$ & 125 & 96 \\
\hline
\end{tabular}

\section{Reagents}

All reagents used were analytical-reagent grade. Either the assay values of the actual batch reported by the manufacturer were accepted, or the chemicals were analysed by wet-chemical methods ${ }^{5-7}$.

The preparation of the flux (45 parts of anhydrous sodium tetraborate, 7 parts of lithium hydroxide, and 16 parts of orthoboric acid) has already been described ${ }^{4}$. Solid dilutions of compounds in flux or borax were used in order to weigh any prescribed small amounts of components accurately. 
In order to calculate the amount of each component required, assay values and losses resulting from ignition were taken into account.

Procedures

Major constituents. Accurately weigh $250 \pm 1 \mathrm{mg}$ of powdered PZT sample into a Degussa II platinum crucible and add $1200 \pm 1 \mathrm{mg}$ of tungsten(VI) oxide and $6500 \pm 2 \mathrm{mg}$ of flux*. Mix the powders, melt and pour a glass disc as previously described ${ }^{4}$. Measure the intensity of the major elements of the sample and of a standard glass disc, under the conditions shown in Table I. Correct for daily variation. Calculate the content of the major constituents, applying the formulae described above with constants determined from the intensities of standards prepared from assayed compounds.

Magnesium dope. Accurately weigh about $100 \mathrm{mg}$ of powdered PZT sample and dissolve in $2.5 \mathrm{ml}$ of perchloric acid $(70 \%)$. Add $2.5 \mathrm{ml}$ of concent rated hydrochloric acid and heat until practically all the hydrochloric acid has evaporated, to dissolve the last traces. Transfer the solution to a volumetric flask and dilute with water to $100 \mathrm{ml}$ for expected concentrations of $0.1-0.3 \% \mathrm{Mg}$. If a higher concentration is expected, dilute more.

Prepare in $50-\mathrm{ml}$ volumetric flasks, solutions containing $25 \mathrm{ml}$ of the above sample solution, $25 \mathrm{mg}$ of strontium chloride (as a solution) and increasing amounts of magnesium as chloride (e.g. $0,2.5,5.0,7.5$ etc. $\mathrm{mg} \mathrm{Mg}$ ). Dilute with water to the mark. Measure the absorbance of these solutions under the conditions shown in Table II. Calculate the magnesium content of the sample by the method of standard additions ${ }^{8}$.

Other dopes. Accurately weigh $2000 \pm 5 \mathrm{mg}$ of powdered PZT into a Degussa II platinum crucible. Add an accurately weighed amount of internal standard (see Table 1) as a solid dilution (e.g. 1:10) in borax. Add powdered borax to give a total weight of $5000 \pm 2 \mathrm{mg}$. Mix the powder, melt and pour a glass disc as previously described ${ }^{4}$. Measure the ratio of intensities of dope element and internal standard, under the conditions shown in Table l. Calculate the dope content from a calibration line, determined from the ratios of intensities in standards, prepared from assayed compounds.

Unreacted lead oxide. Accurately weigh about $250 \mathrm{mg}$ of powdered PZT sample into a dry stoppered flask and add $50.0 \mathrm{ml}$ (or $100.0 \mathrm{ml}$ for high concentrations of unreacted lead) of $0.02 \mathrm{M}$ EDTA solution. Shake the flask for $30 \mathrm{~min}$. Allow the insoluble matter to settle and filter the solution through a dry fineporosity filter. Discard the first $5 \mathrm{ml}$. The filtrate should be clear. Determine the absorbance of the filtrate by atomic absorption, under the conditions described in Table II. Calculate the lead content from a calibration line determined from the absorbances of standards prepared from lead nitrate and EDTA.

Unreacted zirconium and titanium oxide. Accurately weigh about $250 \mathrm{mg}$ of powdered PZT sample. Dissolve in $50 \mathrm{ml}$ of hot concentrated hydrochloric acid. Add $50 \mathrm{ml}$ of hot water and filter through a fine-porosity filter. Wash with hot water. Ash the filter in a Degussa II platinum crucible. Add $500 \pm 2 \mathrm{mg}$ of a solid mixture of

* If standards and samples are not prepared with the same batch of flux, the amount of nux is: $6500 y / y^{\prime}$, where $y^{\prime}$ and $y^{\prime}$ are the residues on ignition of standard batch and new batch of flux respectively. 
lead(II) oxide and sodium chloride ( $6: 1$ by weight). Add $7500 \pm 2 \mathrm{mg}$ of flux, mix the powders. melt and pour a glass disc as previously described ${ }^{4}$. Measure the intensity of zirconium and/or titanium under the conditions shown in Table I. Calculate the zirconium and titanium contents from calibration lines. determined from the intensities of standards prepared from assayed compounds.

\section{DISCUSSION AND RESULTS}

The relative standard deviation found" for the determinations of the major elements was about $0.2 \%$. This standard deviation includes sample inhomogeneity, sample changer dissimilarity, etc.

The absolute standard deviation found for determination of the unreacted oxides is reported in Table III. It was not investigated whether $0.02 \mathrm{M}$ EDTA indeed dissolves only free lead oxide. Robinson and Joyce ${ }^{2}$ do not exclude the possibility of dissolving lead from lead-rich titanium compounds. However, in that case one would expect the measured amount of dissolved lead to depend on the EDTA concentration, and this was not observed. Further, no significant amounts of titanium were found in the EDTA extracts.

TABLE III

COMPARISON OF ANALYSES

\begin{tabular}{|c|c|c|c|}
\hline & $\begin{array}{l}\text { Sample } \\
\text { iolentification }\end{array}$ & $\begin{array}{l}\text { Cleassicesl } \\
\text { me'thods }\end{array}$ & $\begin{array}{l}\text { Proposed } \\
\text { method }\end{array}$ \\
\hline Unrealeted lead & 1 & $1.25 \pm 0.05$ & $1.22 \pm 0.02$ \\
\hline Unreacted zirconium & 1 & $0.60 \pm 0.1$ & $0.65 \pm 0.1$ \\
\hline Unreacted titanium & 1 & $0.02 \pm 0.01$ & $0.03 \pm 0.01$ \\
\hline \multirow[t]{2}{*}{ Total lead } & 1 & $6.3 .7 \pm 0.1$ & $6.3 .6 \pm 0.1$ \\
\hline & 4 & 6.3 .4 & 63.3 \\
\hline \multirow[t]{4}{*}{ Total zirconium } & 1 & $14.78 \pm 0.1$ & $14.88 \pm 0.04$ \\
\hline & 2 & 14.58 & 14.53 \\
\hline & 3 & 13.80 & 13.86 \\
\hline & 4 & 13.71 & 13.69 \\
\hline \multirow[t]{4}{*}{ Total titanium } & 1 & $6.97 \pm 0.05$ & $6.95 \pm 0.02$ \\
\hline & 2 & $6.77^{-}$ & $6.80^{-}$ \\
\hline & 3 & 7.50 & 7.48 \\
\hline & 4 & 7.35 & 7.30 \\
\hline
\end{tabular}

Not enough samples were analysed for dope content to calculate a standard deviation. From the results so far obtained for magnesium, this deviation is expected to be about $5 \%$; for the other dope elements a standard deviation of less than $2 \%$ appeared. In both cases not too low concentrations were present.

The time necessary for the analyses compares very favourably with that of many other methods. The following time requirements do not include the preparation of standards and depend on the length of the series, but include the time necessary for cleaning, calculation and reporting. The simultaneous determination of the three major constituents can be made in about $3 \mathrm{~h}$. Unreacted lead requires about $1.5 \mathrm{~h}$, unreacted zirconium and titanium simultaneously require $3 \mathrm{~h}$. A dope element can be determined in about $1 \mathrm{~h}$, but magnesium requires more time. 
Some representative samples were also analysed by chemical methods ${ }^{5.6}$ (dissolution in hydrochloric acid and fusion of the insoluble residue with pyrosulphate). From the results (Table III) a good precision is apparent. The dopes were not analysed by wet chemistry, because of the difficulties encountered.

We thank Mrs. A. van Veen-Blaauw for the development of the magnesium determination and $\mathrm{Mr}$. H. Weber for much help in preparing standards and analysing samples.

SUMMARY

An accurate X-ray fluorescence spectrometric method is described for the determination of lead, zirconium and titanium in lead zirconate-titanate ceramics. Careful matching of samples and standards by a borax fusion method resulted in a relative standard deviation of about $0.2 \%$ for the major constituents. The determination, after separation, of the unreacted oxide of lead by atomic absorption spectrometry, and of the unreacted oxides of zirconium and titanium by $X$-ray fluorescence spectrometry is also described. An X-ray fluorescence spectrometric method is proposed for the determination of dope elements ( $\mathrm{K}$, La, Sm, Yb) with internal standards ( $\mathrm{Ca}, \mathrm{Ce}, \mathrm{Cr}, \mathrm{Ni}$ respectively). The magnesium dope is determined by atomic-absorption spectrometry with standard addition.

\section{RÉSUMİ}

On décrit une méthode spectrométrique de fluorescence aux rayons-X pour le dosage du plomb, du zirconium et du titane dans des céramiques. Un essayage précautionneux d'échantillons et d'étalons par voie de la méthode de fusion à borax fournissait une déviation standard relative denviron $0.2 \%$ pour les composés principaux. Après séparation, des dosages ont été effectućs pour la partie nonconvertie de l'oxyde de plomb à l'aide d'absorption atomique et pour celle respectivement des oxydes de zirconium et de titanium à l'aide de spectrométrie de fluorescence aux rayons-X. On propose également une méthode pour le dosage des éléments de base (K, La, Sm, Yb) au moyen d'étalons internes (respectivement $\mathrm{Ca}, \mathrm{Ce}, \mathrm{Cr}$ et $\mathrm{Ni}$ ). Le magnésium est dosé spectrophotométriquement par absorption atomique, avec addition d'étalon.

\section{ZUSAMMENFASSUNG}

Es wird eine genaue Röntgenfluoreszenz-Methode beschrieben für die Bestimmung von Blei, Zirkonium und Titan in keramischen Werkstoffen auf Blei-Zirkonat-Titanat-Basis. Durch sorgfailtige Angleichung der Analysen- und Vergleichsproben mittels eines Borax-Schmelzverfahrens wurde für die Hauptbestandteile eine relative Standardabweichung von etwa $0.2 \%$ erzielt. Nach Abtrennung wurden die Oxide bestimmt, dic bei der Herstellung nicht reagiert hatten, und zwar Bleioxid durch Atomabsorptionsspektrometrie und die Oxide von Zirkonium und Titan durch Röntgenfluoreszenzanalyse. Für die Bestimmung der zugesetzten Elemente (K, La, $\mathrm{Sm}, \mathrm{Yb})$ wird ebenfalls eine röntgenfluoreszenzspektrometrische Methode mit 
inneren Standards (resp. $\mathrm{Ca}, \mathrm{Ce}, \mathrm{Cr}, \mathrm{Ni}$ ) vorgeschlagen. Der Magnesium-Zusatz wird durch Atomabsorptionsspektrometrie nach einer Standard-Zumischmethode bestimmt.

\section{REFERENCES}

1 G. C. Goode, J. Herrington and W. T. Jones, Anal. Chim. Acta, 35 (1966) 91.

2 A. E. Robinson and T. A. Joyce, Brit. Ceram. Soc. Trans., 61 (1962) 85.

3 N. A. Mirti and B. Shivak. Tech. Serv. Rept., National Spectrographic Labs., Cleveland, Ohio, 1968. NSL-TSR-250, NSL-Lab-92723 SC-CR-68-3767.

4 3. H. H. G. van Willigen, H. Kruidhof and E. A. M. F. Dahmen, Talanta, 18 (1971) 450.

5 A. I. Vogel, A Texibook of Quantitative Inorganic Analysis, Longmans, London, 3rd Ed., 1962, pp. 333, 434, 547.

6 R. Pribil, Komplexometrie III, VEB Deutscher Verlag für Grundstoffindustric, Leipzig. 1962. p. 93.

7 Komplexometrische Bestimmungsmethoden mit Titriplex, E. Merck AG, Darmstadt, 3rd Ed., p. 40.

8 G. D. Christian and F. J. Feldman, Atomic Absorption Spectroscopt. Wiley Interscience, New York, 1970. p. 206.

9 Instructions for statistical treatment of series of observations: Computation of the standard deviation from the range, Dutch Standards NEN 1047, 3,4 1967.

Anal. Chim. Acra, 62 (1972) 